\title{
Does Circular Reuse of Chickpea Cooking Water to Produce Vegan Mayonnaise Reduce Environmental Impact Compared with Egg Mayonnaise?
}

\author{
Sophie Saget ${ }^{1, * \mathbb{D}}$, Marcela Costa ${ }^{2}$, David Styles ${ }^{2,3}$ and Mike Williams ${ }^{1}$ \\ 1 Department of Botany, School of Natural Sciences, Trinity College Dublin, Dublin 2, D02 PN40 Dublin, Ireland; \\ willimsm@tcd.ie \\ 2 School of Natural Sciences, Bangor University, Bangor LL57 2DG, UK; marcela.costa@bangor.ac.uk (M.C.); \\ David.Styles@ul.ie (D.S.) \\ 3 Bernal Institute, School of Engineering, University of Limerick, V94 T9PX Limerick, Ireland \\ * Correspondence: sagets@tcd.ie
}

Citation: Saget, S.; Costa, M.; Styles, D.; Williams, M. Does Circular Reuse of Chickpea Cooking Water to

Produce Vegan Mayonnaise Reduce Environmental Impact Compared with Egg Mayonnaise? Sustainability 2021, 13, 4726. https://doi.org/ 10.3390/su13094726

Academic Editor: Antonio Zuorro

Received: 24 March 2021

Accepted: 20 April 2021

Published: 23 April 2021

Publisher's Note: MDPI stays neutral with regard to jurisdictional claims in published maps and institutional affiliations.

Copyright: (c) 2021 by the authors. Licensee MDPI, Basel, Switzerland. This article is an open access article distributed under the terms and conditions of the Creative Commons Attribution (CC BY) license (https:// creativecommons.org/licenses/by/ $4.0 /)$.

\begin{abstract}
Consumers are increasingly asking for foods that are healthier, more humane, and environmentally sustainable. Recently, chickpea cooking water-aquafaba-has gained popularity as a potential egg substitute that complies with these criteria. However, research on the environmental impact of this ingredient is lacking. We performed a comparative attributional life cycle assessment (LCA) of mayonnaise made with aquafaba as the emulsifying agent, and traditional mayonnaise made with egg yolk. The vegan mayonnaise was found not to be as environmentally sustainable as the egg-based product. The vegan mayonnaise had a significantly $(p<0.05)$ lower impact across 4 categories, but a significantly higher impact across 8 categories out of 16 , including climate change and resource-use-energy-carriers. The majority of categories under which vegan mayonnaise underperformed were related to the electricity needed for aquafaba processing. These impacts can be mitigated with a "cleaner" electricity grid, or onsite renewable electricity generation. Substituting the Mexican grid, where the aquafaba is currently processed, for the Canadian grid, where the mayonnaise is produced, reduced the carbon footprint of the vegan mayonnaise by $37 \%$, making it similar to the egg-based product. As sunflower oil production was linked to extensive environmental burdens, we performed additional sensitivity analyses around oil processing, sunflower production, and other vegetable oils. Our study shows that substituting egg yolk with aquafaba could cause an increase in the environmental footprint of mayonnaise due to high processing costs, illustrating that vegan options do not always have a smaller environmental footprint, and can represent a trade-off in their comparatively more humane and healthier offer.
\end{abstract}

Keywords: comparative life cycle assessment; legumes; mayonnaise

\section{Introduction}

Consumers are progressively replacing animal proteins with plant-based ones in their diets, as they increasingly search for improved sustainability and healthiness [1]. However, whether these products are more environmentally sustainable and healthy is situation dependent, depending on the origin and processing involved. Indeed, although foods that are healthier generally also have a lower environmental footprint [2-5], this does not always hold true [6,7]. One step further to increase food sustainability may be the replacement of animal products with what used to be waste products. Aquafaba- "bean water" in Latin-is a term used to describe the cooking water of chickpeas. Originally a waste stream, it can be used as an egg replacer thanks to its foaming and emulsifying properties, with the perspective to increase sustainability of food production, being cruelty free $[1,8]$ and more healthy, through the reduction of cholesterol intake $[9,10]$. The use of aquafaba in novel food formulations is becoming increasingly popular, and the ingredient 
can be found in vegan sweet and savoury products, such as in meringues, dairy substitutes and mayonnaise [11].

Mayonnaise is a popular condiment traditionally composed of egg yolk, oil, and vinegar or lemon juice. More than 6.5 million people reported consuming mayonnaise more than once a week in the UK in 2018, alongside 3.4 million in Spain, and 4.5 million in France [12-14]. The global mayonnaise market was estimated at US\$ 10.8 billion in 2019 and is expected to reach US\$ 13.27 billion by 2026 [15]. In Spain, it was reported that 52.8 thousand tons of mayonnaise were consumed in 2019 [16]. This consumption habit, however, does not come burden free. Although eggs have a comparatively lower environmental footprint than other animal sources, they are often associated with a higher carbon footprint than autotrophic protein sources [17], hence the potential of aquafaba as a more environmentally-sustainable egg substitute in mayonnaise.

So far, research has solely focused on the functional and nutritive properties of aquafaba $[1,8,11,18]$. As aquafaba is becoming increasingly popular, it is key to assess its comparative environmental efficiency as a substitute, and whether its use is relevant in the context of the food-health-environment nexus, as this has not been done so far. Life cycle assessment (LCA) is a commonly used technique to quantify the environmental impact of a product or service, by looking at all inputs and outputs in a defined system, from farm to factory gate, or down through to consumption, disposal, or recycling [19], including for food products [20]. These inputs and outputs are linked to elementary flows, which are associated with specific impact factors corresponding to environmental issues, such as climate change, water scarcity, energy use, or nutrient pollution.

To our knowledge, only one published LCA study looked at the environmental impact of traditional, egg-based mayonnaise [21], and none of the other mayonnaise types. In the existing mayonnaise study, rapeseed oil was found to contribute to slightly more than $50 \%$ of the mayonnaise total carbon footprint, followed by packaging glass (21\%) and energy consumption at the manufacturing plant (13\%). The authors found that one $600 \mathrm{~g}$ jar of mayonnaise was responsible for $1.17 \mathrm{~kg} \mathrm{CO}_{2}$ equivalent.

In addition to these environmental concerns, consumers are increasingly aware of the animal welfare issues related to the egg industry [22]. The number of vegans in the world varies by sources, and a recent survey [23] estimated that the share of vegans in selected European countries is approximately 1\% of the total population. What is certain is that veganism is gaining popularity globally, with the number of individuals identifying themselves as vegan rising by 600\% in the US between 2014 and 2017 [24], and quadrupling in the UK between 2014 and 2018 [25].

Egg is commonly substituted in foods such as in pasta, meringue, and mayonnaise with legume-based ingredients. Numerous vegan egg substitutes are commercially available and made, for example, from mung bean protein isolate [26], soy or pea protein isolates [27,28], chickpea flour [29], or potato starch [30]. Some studies compared the carbon footprint of the egg product and its plant-based alternative [31], finding that the legume pasta emits 35.5\% less GHG emissions than the egg alternative.

In this study, we hypothesised that the aquafaba-based vegan mayonnaise (VEG) has a lower environmental footprint than the conventional egg-based mayonnaise (EGG). If this holds true, for the first time, to our knowledge, the aquafaba will be validated as an ingredient that complies with the demand for foods that are altogether healthier, more humane, and more environmentally sustainable.

\section{Materials and Methods}

\subsection{Goal, Scope and Boundary Definition}

This study is a comparative attributional LCA. The open source software OpenLCA v1.10 [32] was used to calculate the environmental footprint of the two products from cradle to factory gate, using Agri-footprint v3.0 [33] and Ecoinvent v3.6 [34] international databases. Inventory data on the VEG and EGG were collected specifically for this study from a company manufacturing both products. 
One functional unit (FU) was used: a $473 \mathrm{~mL}$ glass pot filled with mayonnaise at factory gate from the anonymous company. Two reference flows were compared: a $473 \mathrm{~mL}$ glass pot filled with VEG at factory gate, and a $473 \mathrm{~mL}$ glass pot filled with EGG at factory gate. Figure 1 illustrates the system boundaries used and manufacturing steps for the cradle to gate assessment of VEG and EGG. The environmental impacts of the two products were compared across sixteen environmental impact categories recommended in the Product Environmental Footprint (PEF) Category Rules Guidance [35]. Results were then normalised by global person equivalents, using the factors recommended in the PEF guide [35]. This was done to facilitate interpretation of impact scores.

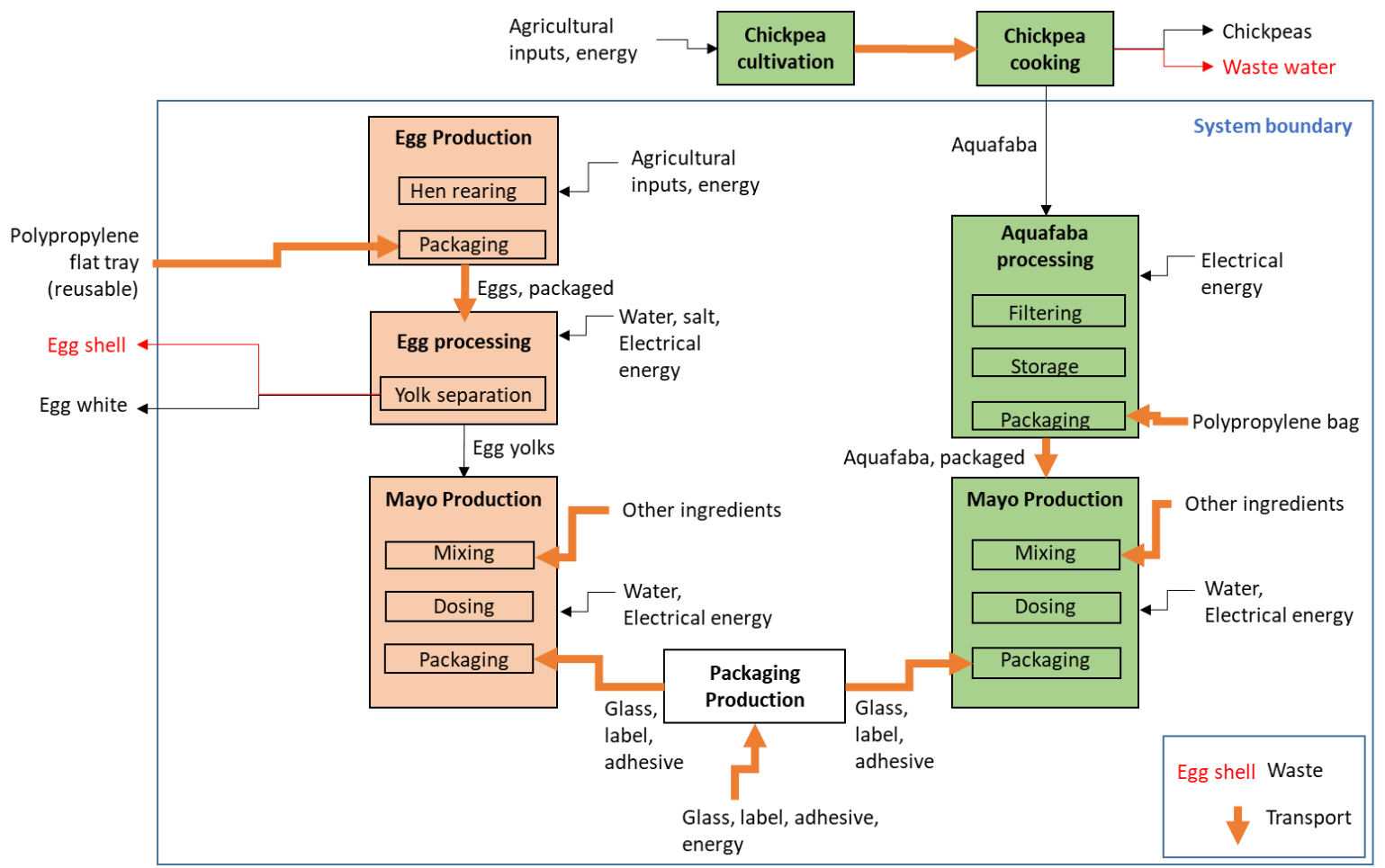

Figure 1. System boundary of vegan (in green) and egg (in red) mayonnaise production, from cradle to factory gate.

To assess the sensitivity of aquafaba environmental footprints to different regional electricity mixes used for processing, we investigated the environmental burdens stemming from a hypothetical vegan mayonnaise product (CA). This theoretical scenario assumed that chickpeas would be grown in Canada, resulting in a different transport distance (the same as for the eggs in EGG) and electricity grid (electricity from Canadia, Ontario) than VEG. This scenario was chosen, as it is directly comparable with EGG. We performed a modified null hypothesis significance test (NHST) following the same approach as in [36], with 1000 Monte Carlo simulation results for each VEG, EGG, and CA products. The modified NHST investigated whether the production of mayonnaise with egg yolk or aquafaba had a statistically $(p<0.05)$ significant different environmental impact for each of the $16 \mathrm{impact}$ categories. To exclude false positives, a Bonferroni correction of $\alpha_{b}=0.05 / 48=0.001042$ was applied. The denominator value was determined with the sixteen environmental impact categories assessed and the three alternative pairs. The effect size was set as $\delta_{0}=0.2$.

With sunflower oil being a key ingredient amounting to approximately $70 \%$ of the total recipe ingredients by weight, three additional aspects of the LCA were investigated:

(A) How sensitive are the environmental burdens of sunflower oil production to a different production method?

(B) How sensitive are the environmental burdens of sunflower oil production to different geographical origins?

(C) How does sunflower oil production compare with oils from different crops? 
To answer (A), two methods of sunflower oil production available in the Agri-footprint v3.0 database - pressing or solvent extraction - were compared using oil yield as a comparison unit [33]. To answer (B), processes for sunflower oil production from Argentina, China, and Ukraine from the Agri-footprint v3.0 database were compared [33]. Finally, the environmental impacts of using a different type of oil to produce mayonnaise were investigated to answer (C). Rapeseed, soybean, and rice bran oils were selected after asking the mayonnaise company which oils could be used in its mayonnaise. As recommended by the PEF guidelines, transport distances used to answer (C) were extracted from Searates [37] for the ship distances, and the truck ones were set at $1000 \mathrm{~km} t$ from harbour/airport to account for the road transport between the factory and the harbour [35]. These distances were recorded in Table A1 (Appendix A).

\subsection{Mayonnaise Inventory}

Data on the recipe, origin of ingredients, and chickpea agricultural phase of the VEG were collected from the mayonnaise manufacturing company. Inputs and outputs to all processes involved in the life cycle of the VEG and EGG, from cradle to factory gate, were recorded but due to intellectual property information, ingredients were grouped into a black box and presented in Table 1. Relevant background processes for production of both mayonnaise types were extracted from LCA databases Ecoinvent 3.6 [34] and Agrifootprint 3.0 [33]. Sunflower oil was imported from Argentina. As a conservative approach, the pressing method for sunflower oil production was selected.

All ingredients are transported to the mayonnaise factory in Canada. The energy required to mix and package the mayonnaise ingredients into the final pot was not available, and was therefore assumed to be the same as in [38] for both the VEG and EGG. The obtained mayonnaise undergo the same packaging process, into a $473 \mathrm{~mL}$ glass pot.

\subsubsection{Vegan Mayonnaise}

The main ingredient of differentiation in the VEG was the use of the aquafaba instead of egg yolk. The aquafaba is produced in Mexico. The International Reference Life Cycle Data System (ILCD) handbook stipulates that the economic value of the co-products is determined at the point, condition, and amount provided by that particular multifunctional process, and not at a later stage [39]. Therefore, because at the point of chickpea cooking, the cooking water is treated as waste, the environmental burdens of chickpea cultivation and processing were entirely attributed to the cooked chickpeas, leaving the unprocessed aquafaba as a burden-free product. The aquafaba is then further processed and packaged in polypropylene bags, consuming $3.59 \mathrm{kWh}$, and sent to a factory in Canada, where it is mixed with water and other ingredients, and the obtained mayonnaise is packaged in a $473 \mathrm{~mL}$ glass pot, consuming $0.4 \mathrm{Wh}$.

\subsubsection{Egg Mayonnaise}

The agricultural data for eggs was obtained directly from the mayonnaise manufacturer and used to modify the existing the Agri-footprint v3.0 egg production process [33]. After collection in Canada, eggs are packaged into polypropylene flat trays and transported to the mayonnaise factory in Canada, where the egg white, shell, and yolk are separated. The egg packaging was assumed to be reused 50 times, as a conservative approach. The energy and water required for this separation step was unknown, and was therefore assumed to be $1.29 \mathrm{kWh}$ for $2.18 \mathrm{~kg}$ pasteurized egg yolk, as in [40]. All energy sources (electricity, natural gas, diesel, and gasoline) from [40] were modelled as electricity in this study. A study [41] found that the emissions stemming from the egg processing and breaking stages were relatively minor, representing 1 to $2 \%$ of the total emissions from the whole egg supply chain, hence approximating these was not considered to be a major limitation. After being checked, the egg is washed and broken down. Egg yolk and white are then separated. The egg yolk is homogenised, refrigerated and subsequently pasteurised. The environmental burdens of the egg chain were economically attributed between egg whites and yolks, as 
egg shells were considered as waste. Dried egg white is worth between 4.5- and 8-foldmore than dried egg yolk [42]. In this study, we assumed it was worth the median of this range, 6.25 -fold more than dried egg yolk. With a water content of $55 \%$ in egg yolk and $87.7 \%$ in egg whites [43], a fresh weight content of $30 \%$ of egg yolk and $60 \%$ of egg white in one egg, the allocation factors were economically calculated and amounted to 0.39 for the egg yolks and 0.61 for the egg whites. The obtained EGG mayonnaise is then packaged in the same fashion as for the VEG, as described in Section 2.2.

Table 1. Inventory for the $473 \mathrm{~mL}$ pot of vegan (VEG) and egg (EGG) mayonnaise modelled in this study. "Confid." relates to the confidential recipe of the mayonnaise company.

\begin{tabular}{|c|c|c|c|c|c|c|}
\hline \multirow[t]{2}{*}{ Stage } & \multirow[t]{2}{*}{ Input/Output/Process } & \multirow[t]{2}{*}{ Units } & \multicolumn{2}{|c|}{ VEG } & \multicolumn{2}{|c|}{ EGG } \\
\hline & & & In & Out & In & Out \\
\hline \multirow{8}{*}{ Egg production } & Feed and supplements & $\mathrm{kg}$ & & & 0.28 & \\
\hline & Land & $\mathrm{kg}$ & & & 0.66 & \\
\hline & Energy & kWh & & & 0.01 & \\
\hline & Laying hen & Item & & & 0.01 & \\
\hline & Water & $\mathrm{L}$ & & & 0.45 & \\
\hline & Transport, truck $>32 \mathrm{t}$ & $\mathrm{kg} \cdot \mathrm{km}$ & & & 0.28 & \\
\hline & Laying hen & $\mathrm{kg}$ & & & & 0.008 \\
\hline & Egg & $\mathrm{kg}$ & & & & Confid. \\
\hline \multirow{2}{*}{ Aquafaba processing } & Energy & kWh & 3.59 & & & \\
\hline & Aquafaba & $\mathrm{kg}$ & \multicolumn{3}{|c|}{ Confid. } & \\
\hline \multirow{6}{*}{$\begin{array}{l}\text { Aquafaba/egg packaging and } \\
\text { transport }\end{array}$} & Polypropylene & $\mathrm{kg}$ & 0.11 & & 0.027 & \\
\hline & Forming of packaging & $\mathrm{kg}$ & 0.11 & & 0.027 & \\
\hline & Packaging transport, truck $>32 \mathrm{t}$ & kg.km & 25.0 & & 0.12 & \\
\hline & Packaging transport, train & kg.km & 30.4 & & 0.15 & \\
\hline & Packaging transport, ship & kg.km & 39.1 & & 0.19 & \\
\hline & Transport to mayo factory, truck $>32 \mathrm{t}$ & $\mathrm{kg} \cdot \mathrm{km}$ & 805.5 & & 653.5 & \\
\hline \multirow{6}{*}{ Egg processing } & Water & $\mathrm{L}$ & & & 0.42 & \multirow{6}{*}{$\begin{array}{l}\text { Confid. } \\
\text { Confid. } \\
\text { Confid. }\end{array}$} \\
\hline & Processing energy & kWh & & & 0.022 & \\
\hline & Salt & $\mathrm{kg}$ & & & 0.004 & \\
\hline & Egg yolk & $\mathrm{kg}$ & & & & \\
\hline & Egg shell & $\mathrm{kg}$ & & & & \\
\hline & Egg white & $\mathrm{kg}$ & & & & \\
\hline \multirow[t]{7}{*}{$\begin{array}{l}\text { Other Ingredients production, } \\
\text { processing, and transport }\end{array}$} & $\begin{array}{l}\text { Sunflower oil from crushing } \\
\text { (pressing)-AR }\end{array}$ & $\mathrm{kg}$ & Confid. & & Confid. & \\
\hline & Oil transport, truck $>32 \mathrm{t}$ & kg.km & 893 & & 995 & \\
\hline & Oil transport, ship & $\mathrm{kg} . \mathrm{km}$ & 4360 & & 4860 & \\
\hline & Water & L & & & 0.037 & \\
\hline & Other ingredients & $\mathrm{kg}$ & 0.04 & & 0.38 & \\
\hline & Ingredients transport truck $>32 \mathrm{t}$ & kg.km & 39 & & 31 & \\
\hline & Ingredients transport ship & $\mathrm{kg} \cdot \mathrm{km}$ & 476 & & 232 & \\
\hline \multirow[t]{5}{*}{ Packaging } & Glass & $\mathrm{kg}$ & 0.203 & & 0.203 & \\
\hline & Graphic paper, $100 \%$ recycled & $\mathrm{kg}$ & 0.0009 & & 0.0009 & \\
\hline & Dichloromethane & $\mathrm{kg}$ & 0.0001 & & 0.0001 & \\
\hline & Steel cap & $\mathrm{kg}$ & 0.011 & & 0.011 & \\
\hline & Packaging trans, lorry, $>32 \mathrm{t}$ & $\mathrm{kg}^{*} \mathrm{~km}$ & 484.3 & & 484.3 & \\
\hline \multirow{2}{*}{ Mayonnaise production } & Electricity for assembling & $\mathrm{kWh}$ & \multirow[t]{2}{*}{0.0004} & \multirow{2}{*}{\multicolumn{2}{|c|}{0.0004}} & \\
\hline & Mayonnaise pot, at factory & item & & & & 1 \\
\hline
\end{tabular}

\section{Results}

\subsection{General Environmental Results}

The environmental burdens of the two mayonnaise types are recorded in Table 2. The two products had large environmental footprint differences across various categories, with VEG having an $80 \%$ higher carbon footprint and a 1.3-fold higher resource-use-energycarriers burden than those of EGG. The EGG mayonnaise had a $10 \%$ and $12 \%$ higher terrestrial eutrophication and land use burdens than VEG. The Monte Carlo analyses and the modified NHST showed that the VEG had a significantly lower environmental impact from EGG across the cancer human health, ecotoxicity freshwater, land use, and resource use minerals and metals categories, while EGG had a significantly lower environmental 
impact across 8 categories out of 16, including acidification, climate change, and resourceuse-energy-carriers (Table 2).

Table 2. Summary of environmental burdens for the vegan (VEG) and egg-based (EGG) mayonnaises, expressed per 473 $\mathrm{mL}$ pot of mayonnaise. Shaded cells in grey indicate the impact categories in which the product has a significantly larger environmental impact than the other mayonnaise.

\begin{tabular}{lccc}
\hline Name & Unit & VEG & EGG \\
\hline Acidification terrestrial and freshwater & mol H ${ }^{+}$eq & 0.022 & 0.019 \\
Cancer human health effects & CTUh & $6.3 \times 10^{-8}$ & $5.5 \times 10^{-8}$ \\
Climate change & $\mathrm{kg} \mathrm{CO}_{2}$ eq & 3.6 & 2.0 \\
Ecotoxicity freshwater & $\mathrm{CTUe}$ & 25.7 & 27.6 \\
Eutrophication freshwater & $\mathrm{kg} \mathrm{P} \mathrm{eq}$ & 0.00089 & 0.00038 \\
Eutrophication marine & $\mathrm{kg} \mathrm{N} \mathrm{eq}$ & 0.011 & 0.011 \\
Eutrophication terrestrial & $\mathrm{mol} \mathrm{N} \mathrm{eq}$ & 0.057 & 0.063 \\
Ionising radiation, human health & $\mathrm{kBq} \mathrm{U}-235$ eq & 0.243 & 0.096 \\
Land use & Point & 799 & 897 \\
Non-cancer human health effects & $\mathrm{CTUh}$ & $1.1 \times 10^{-6}$ & $1.1 \times 10^{-6}$ \\
Ozone depletion & $\mathrm{kg} \mathrm{CFC-11} \mathrm{eq}$ & $2.7 \times 10^{-7}$ & $1.2 \times 10^{-7}$ \\
Photochemical ozone formation, human health & $\mathrm{kg} \mathrm{NMVOC} \mathrm{eq}$ & 0.012 & 0.008 \\
Resource use, energy carriers & $\mathrm{MJ}$ & 46.9 & 20.4 \\
Resource use, mineral and metals & $\mathrm{kg} \mathrm{Sb} \mathrm{eq}$ & $3.3 \times 10^{-7}$ & $3.7 \times 10^{-7}$ \\
Respiratory inorganics & disease inc. & $1.7 \times 10^{-7}$ & $1.6 \times 10^{-7}$ \\
Water scarcity & $\mathrm{m}^{3}$ depriv. & 1.13 & 1.18 \\
\hline
\end{tabular}

To understand which categories may represent relatively greater environmental loadings, we performed a normalisation of the results in person equivalents (Figure 2) with PEF-recommended factors [35]. Apart from the toxicity-related categories, for which the normalisation factors are highly uncertain [35], between the VEG mayonnaise categories, the highest burdens were resource-use-energy-carriers, land use, climate change, acidification, and the three eutrophication types, with a burden of at least $3 \times 10^{-4}$ person equivalents per pot of mayonnaise. Between the EEG mayonnaise categories, these were the same excepted for climate change and freshwater eutrophication, for which the burdens were smaller than $3 \times 10^{-4}$ person equivalents. VEG had a significantly higher $(p<0.05)$ environmental impact across 4 categories, with the highest top 7 normalised scores-acidification, climate change, resource-use-energy-carriers, freshwater and eutrophication-while EGG had a significantly higher $(p<0.05)$ environmental impact across 1 of them, land use.

A process contribution graph was recorded in Figure 3, so as to identify hotspots across the life cycle. Sunflower oil production was responsible for most of the impact across the majority of categories. Sunflower oil production was responsible for $59 \%$ of the total cancer human health burdens of VEG and 76\% for EGG, mainly due to the emission of chromium to water from sunflower seed production. It was also responsible for $82 \%$ and $88 \%$ of the total non-cancer human health effects of VEG and EGG, respectively, due to zinc emission to soil. In the ecotoxicity freshwater category, sunflower oil production was responsible for $90 \%$ of the total burdens VEG and $93 \%$ of EGG due to the emission of the insecticide alpha-cypermethrin to water. Sunflower oil production was also responsible for $99 \%$ and $98 \%$ of land use burdens for VEG and EGG, respectively. For the EGG mayonnaise, resource-use-energy-carriers burdens were due to sunflower seed production with $67 \%$ of the total burdens, and an additional $21 \%$ from the glass pot for the mayonnaise. For the VEG mayonnaise, $26 \%$ of total burdens in this category were due to sunflower seed production, and 14\% from the aquafaba polypropylene packaging. In the climate change category, sunflower oil was responsible for $37 \%$ of total VEG burdens. 


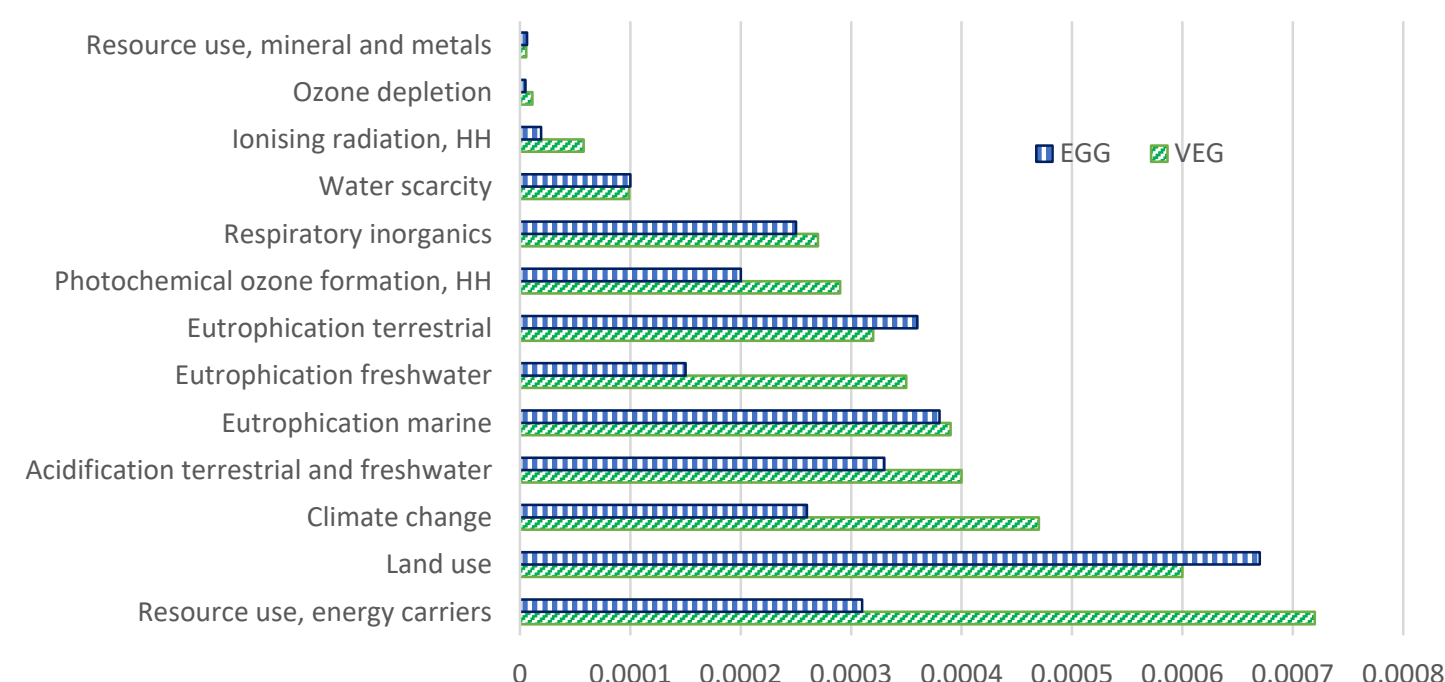

Figure 2. Normalised environmental results of a pot of vegan (VEG) and egg (EGG) mayonnaise across all impact categories assessed, excepted for the toxicity-related ones, due to highly uncertain normalisation factors, following Product Environmental Footprint guidelines [35].
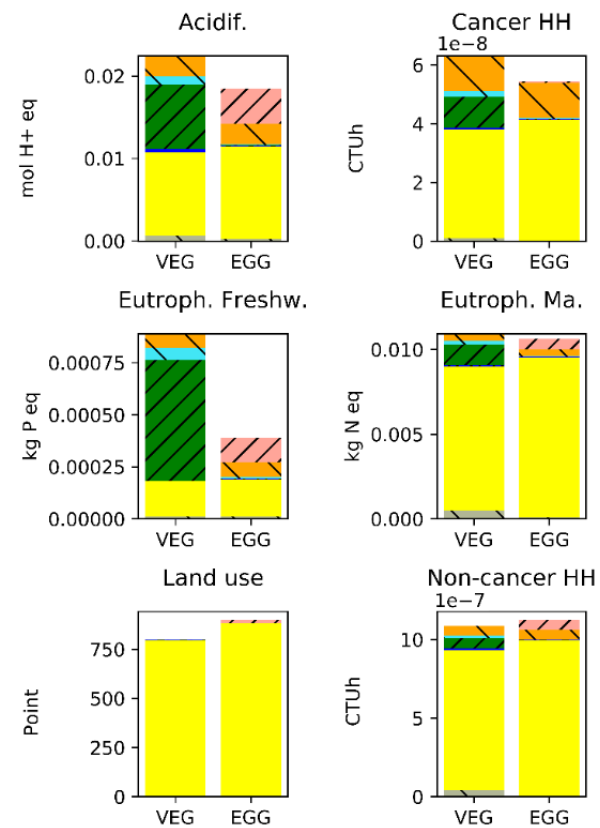

$\mathrm{RU}$, energy car.

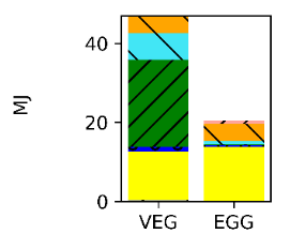

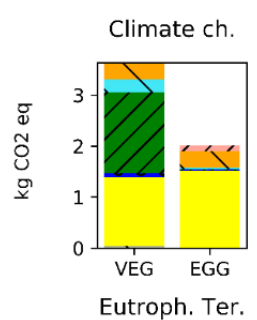
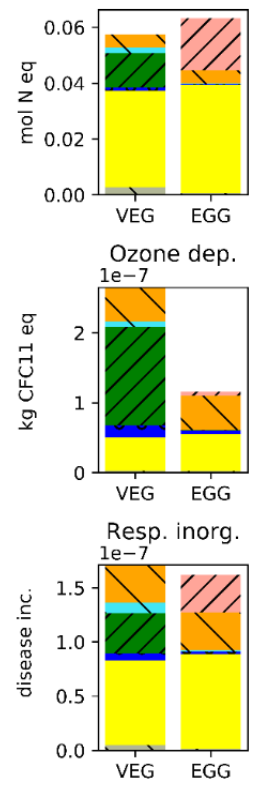
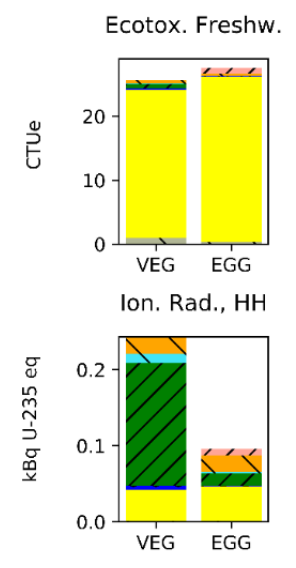

Phot. Oz. form., HH
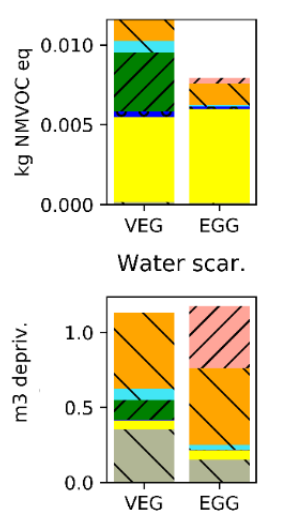

\begin{tabular}{|lllll|}
\hline Ingredients assembling & Sunflower oil & Aquafaba/egg processing & Packaging \\
Other ingredients & Aquafaba/egg transport & Aquafaba/egg packaging & \multicolumn{1}{|l}{ Egg production } \\
\hline
\end{tabular}

Figure 3. Process contributions of vegan (VEG) and egg (EGG) mayonnaise across the sixteen environmental impact categories recommended by the Product Environmental Footprint guidelines. 
In addition to the high environmental share of sunflower oil, the electricity usage for aquafaba processing was responsible for a major portion of the environmental burdens, including $44 \%$ of the total carbon footprint, $47 \%$ of total resource-use-energy-carriers, and $90 \%$ of the total freshwater eutrophication. Sources of the Mexican electricity mix are a combination of natural gas, oil, and lignite, amongst others, which are an important source of carbon dioxide emissions to the air. Egg production for the EGG mayonnaise was responsible for $23 \%$ of its total acidification burden and $29 \%$ of its total terrestrial eutrophication, due to the release of ammonia to the air. Egg production was also the cause of $35 \%$ of its total water scarcity footprint due to feed irrigation, and $21 \%$ of the total respiratory inorganics burden due to ammonia and particulate matters that are less than $10 \mu \mathrm{m}$ release to the air.

\subsection{Sensitivity Analyses}

\subsubsection{Electricity for Aquafaba Processing}

The electricity use for aquafaba processing has a major impact on the comparative environmental performance of the vegan mayonnaise. This step was responsible for the VEG mayonnaise having a higher environmental burden than EGG across 6 categories out of 16, including freshwater and marine eutrophication. The process contribution results that comprise the additional scenario, CA were recorded in Figure A1. The environmental performance of CA was considerably smaller than that of VEG across most categories, with a $37 \%$ lower climate change footprint, a $32 \%$ lower acidification burden, and a $62 \%$ lower freshwater eutrophication burden. The carbon footprint of CA is $13 \%$ higher than that of EGG, while the carbon footprint of VEG is $80 \%$ higher than that of EGG. However, CA was associated with a $15 \%$ higher resource-use-energy-carriers burden, and a 4 -fold higher water scarcity burden than VEG.

\subsubsection{Type of Oil Used}

\section{Environmental Differences of Alternative Production Method of Sunflower Oil}

Due to the existence of different sunflower oil production methods, which yield a same final main output product, sunflower oil, we investigated the relative environmental footprint differences between pressing and solvent extraction. The comparison of the environmental burdens of these two approaches was recorded in Figure A2 per final vegan mayonnaise pot. The vegan mayonnaise pot that used a solvent extraction method for its sunflower oil appeared to have an environmental burden that was either equal or lower than the one that used a pressing extraction method. The former had a burden that was between $7 \%$ and $15 \%$ lower across 10 categories out of 16 . However, when running 1000 Monte Carlo runs per option and applying the modified NHST, this different processing method did not change significantly the overall environmental impact of the product (data not shown).

\section{Environmental Differences of Sunflower Oil Production from Varying} Geographical Origins

With different agronomic systems having varying environmental footprints, we assessed the potential magnitude of these disparities using as examples vegan mayonnaise made with sunflower oil from Ukraine (UA), or from China (CN). Figure 4 presents the environmental differences between refined sunflower oil made by pressing from the different countries from cradle to farm gate per pot of vegan mayonnaise. The systems compared differed in the sunflower agronomy stage as well as the electricity grid for oil processing, which was specific to the country in which the sunflower oil was produced. 


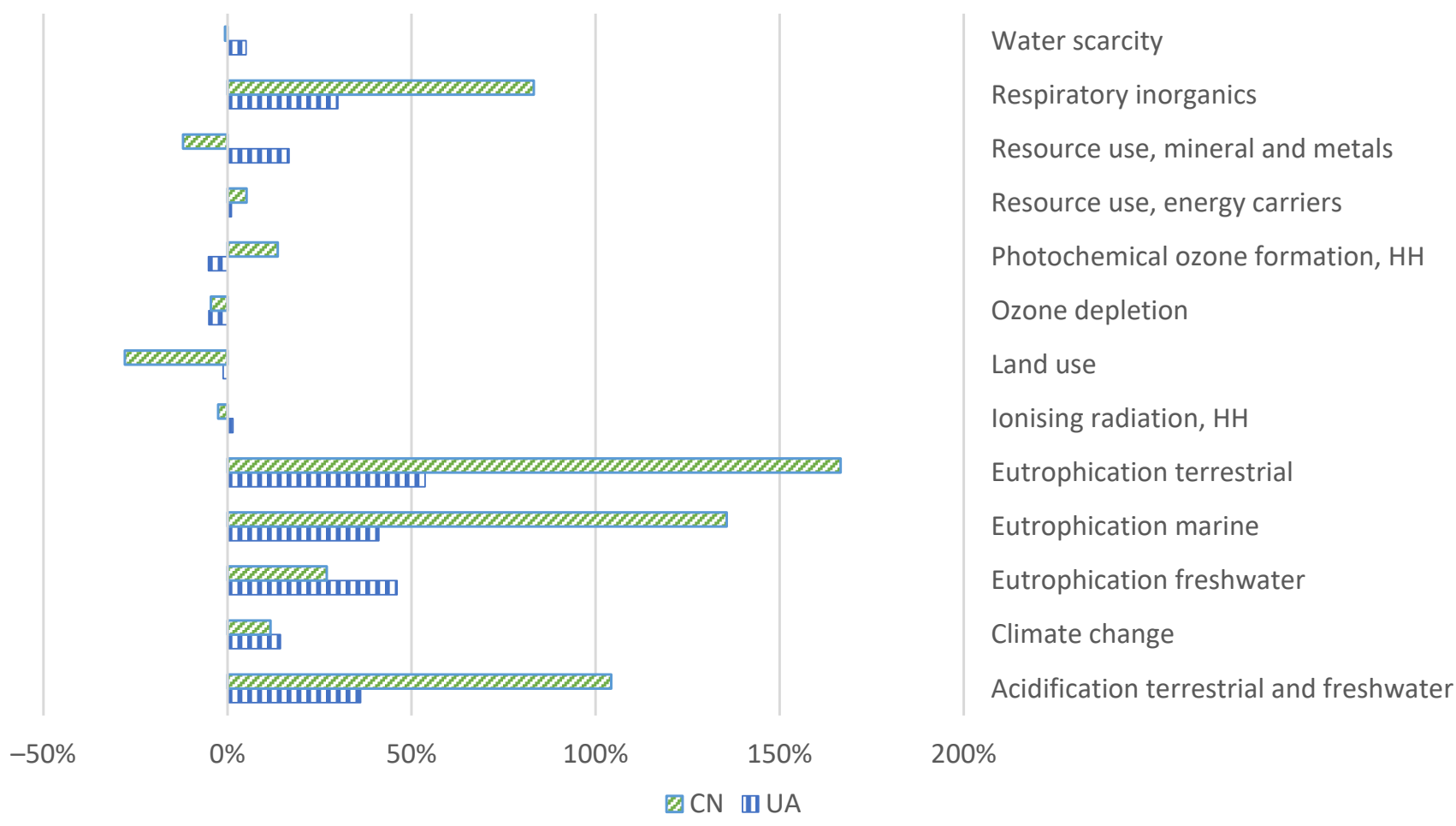

Figure 4. Comparative environmental footprint of vegan mayonnaise made with Argentinian sunflower oil from pressing (reference, on $\mathrm{Y}$ axis at $0 \%$ ), from Ukraine (UA), and China $(\mathrm{CN})$ across the non-toxicity categories recommended by the Product Environmental Footprint guidelines.

The $\mathrm{CN}$ vegan mayonnaise was associated with higher environmental burdens across all categories apart from land use, which was $1 \%$ lower. Burdens from other categories excluding the toxicity ones were between $5 \%$ (photochemical ozone formation) and $266 \%$ (freshwater eutrophication) higher than those of sunflower oil from Argentina. Sunflower oil from China appeared to have a lower environmental impact across 6 categories out of 16, including a $28 \%$ lower land use burden than the Argentinian sunflower oil. Yields were higher for the Chinese sunflower seed production, with $2519 \mathrm{~kg}$ seeds per hectare against $1797 \mathrm{~kg}$ Argentinian seeds per hectare, and $1820 \mathrm{~kg}$ Ukrainian seeds per hectare. Although both the Ukrainian and Chinese systems had a higher yield per hectare than the Argentinian one, they had a higher environmental impact due to more fertiliser inputs per final output (Table A2).

\section{Environmental Differences of Other Vegetable Oils}

With the vegetable oil being the main ingredient in the mayonnaise, we investigated the magnitude of change in the environmental impact of the vegan mayonnaise pot when substituting the Argentinian sunflower with rapeseed (from pressing in Germany), soybean (from pressing in Argentina and Brazil), and rice bran (from China) oil types. Results are presented in Figure 5. All additional options from this sensitivity analysis had a lower land use and resource use minerals and metals burdens than VEG. The only option that was associated with a lower carbon footprint than the current VEG was the vegan mayonnaise made with rapeseed oil from Germany, which had a $8 \%$ lower climate change burden. However, this mayonnaise product had eutrophication burdens that were between $10 \%$ and $89 \%$ higher, and a $46 \%$ higher acidification burden than those of VEG. 


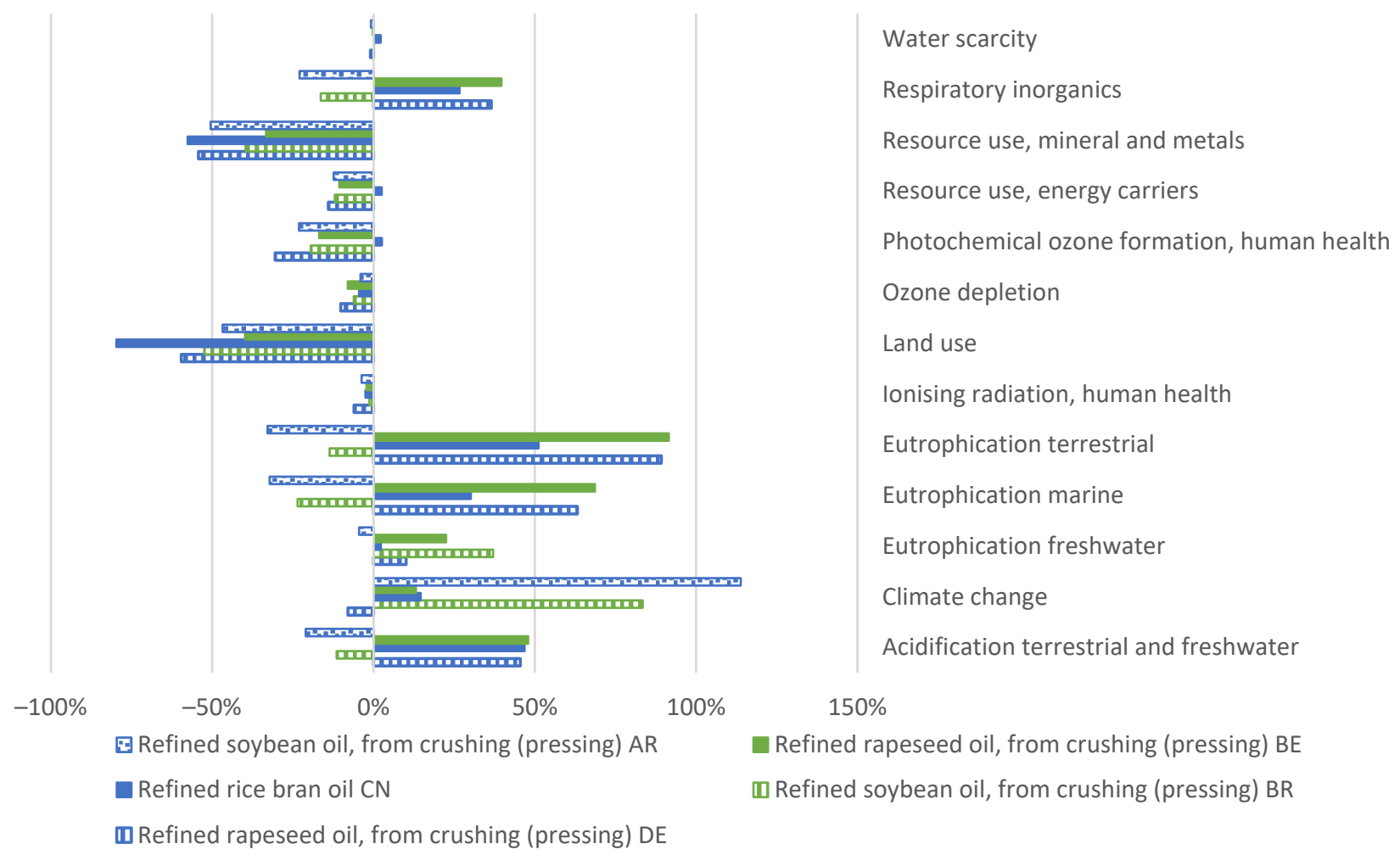

Figure 5. Comparative environmental footprint of vegan mayonnaise made with Argentinian sunflower oil from pressing (reference, on $\mathrm{Y}$ axis at $0 \%$ ), and from vegan mayonnaise made with soybean oil (Brazil-BR and Argentina-AR), rice bran oil (China-CN), and rapeseed oil (Belgium-BE and Germany-DE) across the non-toxicity categories recommended by the Product Environmental Footprint guidelines.

\section{Discussion}

The comparative LCA showed that using aquafaba instead of egg yolk can significantly affect the overall environmental performance of mayonnaise. Our hypothesis that the vegan mayonnaise was associated with lower overall environmental burdens than the egg alternative was shown to be false in our case study, due to the high electricity use for aquafaba processing. Other studies have pointed out that additional processing steps and a comparatively high energy use can critically worsen the environmental advantage of an innovative product [44,45]. Because aquafaba is a recent ingredient, more efficient and less resource-intensive processing methods may be developed in the future, resulting in a significantly lower overall environmental burden for aquafaba-based mayonnaise. Modelling of waste streams at low Technology Readiness Levels (TRLs) is not efficiently performed and the end result may not be representative of the future potential environmental performance of the products [46]. Moreover, the environmental performance of other aquafaba-based products should be investigated, as processing techniques may vary from this case study.

With electricity mixes differing greatly between countries, the contribution of the current aquafaba processing electricity use to the overall mayonnaise environmental impact can vary greatly, depending on where this step takes place. The sensitivity analysis performed with the CA scenario reduced the environmental burdens of the vegan mayonnaise across most categories, including a 37\% reduction of the total carbon footprint, for example. In total, CA had significantly $(p<0.05)$ lower burdens than EGG across 8 categories out of 16 , and 12 out of 16 when compared to the VEG mayonnaise (Table A3). The EGG mayonnaise still had significantly $(p<0.05)$ lower environmental burdens across the same categories when compared with VEG or CA, apart for the freshwater eutrophication and respiratory inorganics categories, across which CA mayonnaise had a significantly lower burden. The CA mayonnaise also had a significantly lower burden than VEG and EGG 
across the terrestrial eutrophication categories. However, EGG had a significantly lower water scarcity burden than that of the CA mayonnaise. It is important to note that the Mexican electricity grid mix process used in this case study is from Ecoinvent v3.6 [34], which is based on 2014 electricity data. As the Mexican government is working to increase its share of clean energy, aiming for it to reach $25 \%$ of total electricity production by 2024 , $43 \%$ by 2030 , and $50 \%$ by 2050 [47], the current and future environmental impact of VEG is likely to be lower than the one presented in this case study, even if the amount of electricity use remains the same.

The contribution analysis showed that sunflower oil was responsible for a major part of the environmental impact in both the VEG and EGG mayonnaises. This finding is in line with the existing published LCA of traditional egg mayonnaise, which found that the oil (rapeseed in their case) was responsible for more than half of the carbon footprint of the product [21]. This does not come as a surprise, as the oil is the main ingredient of the mayonnaise quantity wise. Finding a more environmentally-sustainable oil or oil substitute would therefore have the greatest impact common to both mayonnaises. Our assessment showed that the agronomic approach in various countries had a large influence on the environmental impact of sunflower seed production, with total carbon footprints of vegan mayonnaise varying between $12 \%$ and $14 \%$ more, land use up to $28 \%$ less, and terrestrial eutrophication up to $167 \%$ more than the current sunflower oil from Argentina, amongst others. This high variance between agronomic approaches was also revealed in other studies [17].

In addition to our assumption that a different oil has the same technological requirements as sunflower oil to produce mayonnaise, we showed that substituting the sunflower oil with a different vegetable oil from another geographic region represented significant trade-offs, with the final vegan mayonnaise pot having a carbon footprint between $8 \%$ lower and 114\% higher than VEG, however all options had a land use burden that was between $40 \%$ and $80 \%$ smaller than VEG. A lower land use burden is highly relevant in the context of climate change mitigation, as soil has the capacity to store large quantities of carbon dioxide through ecosystem restoration [48]. Aside from these environmental issues, substituting one vegetable oil for another may also have some consequences on health, due to varying nutritional profiles, especially fatty acids [49]. However, mayonnaise being a major source of dietary fat regardless of the type of oil used, alternatives that are more healthy are being researched extensively [10]. Indeed, high intakes of dietary fats are linked with poor gut microbiota and consequently decreased metabolic health, causing high obesity rates with increased incidence of type 2 diabetes, cardiovascular diseases, and hypertension [50,51]. With more than one in two adults and nearly one in six children being overweight or obese in the Organisation for Economic Co-operation and Development (OECD) countries [52], it is therefore crucial to find healthier alternatives without compromising environmental sustainability, as was shown with the aquafaba substitution with egg yolk in this study. VEG offers a healthier alternative to EGG due to lower energy, cholesterol, sodium, and saturated fat contents per serving (Table A4) and may be more suitable to populations at risk of developing cardiovascular diseases [53]. Nevertheless, mayonnaise remains a highly fatty food, due to its main ingredient being oil, and its consumption should remain limited [49].

As displayed with the sixteen impact categories considered, it is key to evaluate the impact beyond a simple carbon footprint in order to identify trade-offs. Our additional analyses showed that the environmental burdens of oil in the mayonnaise across most categories may be reduced by up to $16 \%$ by adopting a different oil processing method (solvent), and that substituting sunflower with soybean or rice bran were associated with important trade-offs, including across the climate change category, across which the total carbon footprint of oil was be $330 \%$ higher. A consequential LCA that aimed to capture the effects of substituting the average mix of oils with different oils was carried out [54]. The author concluded that an increase in rapeseed and sunflower oils would have the lowest carbon footprint, palm and soybean oils had the lowest land use, and sunflower 
oil had the smallest water use. Due to the key role of restoration of native ecosystems on anthropogenic land use to store atmospheric carbon and main temperature levels below $1.5{ }^{\circ} \mathrm{C}[48,55]$, the fact that land use burdens of all other oils were between $40 \%$ and $80 \%$ lower than the land use burden of the current Argentinian sunflower oil selected as the study baseline is non-negligible.

The environmental impact of the aquafaba packaging was higher than that of the egg packaging, as the eggs were packaged and transported as a whole, with a subsequent separation of yolk, white and shell. This implies that the egg packaging burdens were distributed between the various components, and due to the egg yolks having a lower economic value than egg whites, the egg packaging burdens were therefore mostly allocated to the egg whites, which are not part of the EGG mayonnaise boundaries. If no allocation had been performed, or if the egg yolks had been separated prior to transport to the mayonnaise production factory, the respective environmental impact may have varied significantly.

This study is limited by the fact that secondary processes were used for sunflower seed production and processing into oil. In order to accurately calculate the impact of the use of sunflower oil, primary data on sunflower seed cultivation and oil processing need to be collected. In addition, modelling choices in LCA often differ between studies in terms of what is taken into account (system boundaries), what the unit of comparison is (functional unit), and how the environmental burdens are distributed between co-products of a same process (allocation). These choices can significantly affect results and conclusions of LCA studies. In this study, we collected data for both mayonnaise types from the same food manufacturer, which limited data uncertainty in this aspect. Therefore, results are strictly specific to this case and only provide an overview of the potential impacts and hotspots for the specific products described. Additional environmental assessments need to be performed with data from other mayonnaise manufacturers, as we showed that impacts were very sensitive to the location of aquafaba processing and the agronomic data of sunflower oil, amongst other points. It is also worth noting that as the use of aquafaba to produce mayonnaise avoids wastewater discharge, eutrophication and treatment burdens of the vegan mayonnaise may be reduced if system boundaries were extended to include this point. This has not been performed here, as it is a simple attributional LCA but may be worth investigating in future research.

Nevertheless, this study provides a good overview of the potential environmental consequences of modifying the supply chain of the oil ingredient, and the potentially wide ranges of environmental impact that can be observed for the same end product depending on ingredient sourcing and processing location, a key information that is not readily available to consumers. This highlights the issue that consumers, even with the best intentions, are not sufficiently empowered to choose the most sustainable foods. Furthermore, the environmental LCA performed in this study does not consider other factors that are important to consumers, such as working conditions or animal welfare [20]. It is worth noting that the eggs used by the mayonnaise producer are certified humane and are range free. In addition, the functional unit (1 pot of mayonnaise at factory gate) excluded any taste or texture differences between the traditional and vegan product, which is arguably the most important decision factor for consumers [56].

\section{Conclusions}

Our comparative LCA shows that substituting egg yolk with aquafaba in mayonnaise can result in a significantly higher environmental footprint across major categories including climate change, due to high electricity use for aquafaba processing. Therefore, we highlighted the absolute necessity to perform environmental assessments of novel products, as, even with a burden-free waste vegan product substituting for an animal product, associated environmental burdens of the former can be comparatively higher. We showed that increasing the share of cleaner electricity generation on national grids is likely to reduce the overall impact of the vegan mayonnaise, although important trade-offs can occur across some categories. The environmental hotspot common to both mayonnaises is 
sunflower oil production, and we showed that there is potential to reduce this impact by adopting a different oil production method. In contrast, changing agricultural practises or source regions, and substituting sunflower with soybean or rice bran, were associated with important trade-offs. Thus, for mayonnaise, vegan substitutes and circular reuse of a waste (aquafaba) do not necessarily derive lower environmental impact, despite providing potentially a more humane and healthy alternative.

Author Contributions: S.S.: Conceptualization, Methodology, Writing-Original Draft, and Investigation. M.W.: Writing - Review and Editing and Supervision. M.C.: Writing-Review and Editing. D.S.: Methodology, Writing-Review and Editing, and Supervision. All authors have read and agreed to the published version of the manuscript.

Funding: This research was funded by the EU FRAMEWORK PROGRAMME FOR RESEARCH AND INNOVATION H2020, grant number 727,973.

Institutional Review Board Statement: Not applicable.

Informed Consent Statement: Not applicable.

Data Availability Statement: The data presented in this study are available in this article.

Conflicts of Interest: The authors declare no conflict of interest.

\section{Appendix A}

Table A1. Distances for the different transportation modes to bring the vegetable oil from the country of origin to Canada.

\begin{tabular}{cccccccc}
\hline Transport Mode & Units & UA & CN & AR & BR & DE & BE \\
\hline Oil transport, truck $>32 \mathrm{t}$ & $\mathrm{km}$ & 1000 & 1000 & 1000 & 1000 & 1000 & 1000 \\
Oil transport, ship & $\mathrm{km}$ & 11798 & 27,375 & 13,755 & 14,484 & 7216 & 7254 \\
\hline
\end{tabular}

Table A2. Comparison of fertiliser inputs per $\mathrm{kg}$ of sunflower seed obtained in the Ukrainian, Chinese, and Argentinian agronomic processes from Agri-footprint v3.

\begin{tabular}{ccccc}
\hline & $\begin{array}{c}\mathbf{N} \\
\mathbf{( k g}\end{array}$ & $\begin{array}{c}\text { Manure } \\
\mathbf{( k g )}\end{array}$ & $\begin{array}{c}\mathbf{P} \\
(\mathbf{k g})\end{array}$ & $\begin{array}{c}\text { K } \\
\mathbf{( k g})\end{array}$ \\
\hline Ukraine & 0.0158 & 0.2693 & 0.0203 & 0.0066 \\
China & 0.0423 & 0.6135 & 0.0106 & 0.0052 \\
Argentina & 0.0056 & 0.1493 & 0.0039 & 0 \\
\hline
\end{tabular}

Table A3. Positive results of the modified null hypothesis significance test for the vegan mayonnaise with aquafaba processed in Mexico (VEG), aquafaba processed in Canada (CA), and egg mayonnaise (EGG. Negative values from the Monte Carlo analyses were adjusted to zero (Muller et al., 2016).

\begin{tabular}{|c|c|c|c|c|}
\hline & \multicolumn{4}{|c|}{ Economic Allocation, Weight FU } \\
\hline \multirow{2}{*}{ Meaning of Result > } & \multicolumn{4}{|c|}{ Is the Mean Impact of $j$ at Least 0.2 Standard Deviation Units Significantly Lower than that of $k$ ? } \\
\hline & & No & Yes & \\
\hline \multicolumn{5}{|l|}{ Impact } \\
\hline \multirow{4}{*}{$\begin{array}{l}\text { Acidification terrestrial } \\
\text { and freshwater }\end{array}$} & $\mathrm{j} \downarrow \mathrm{k} \rightarrow$ & VEG & EGG & CA \\
\hline & \multirow{3}{*}{$\begin{array}{l}\text { VEG } \\
\text { EGG } \\
\mathrm{CA}\end{array}$} & & no & no \\
\hline & & yes & & no \\
\hline & & yes & yes & \\
\hline \multirow[t]{4}{*}{ Cancer Human Health } & \multirow{4}{*}{$\begin{array}{l}\text { VEG } \\
\text { EGG } \\
\text { CA }\end{array}$} & VEG & EGG & CA \\
\hline & & & yes & no \\
\hline & & no & & no \\
\hline & & yes & yes & \\
\hline
\end{tabular}


Table A3. Cont.

\begin{tabular}{|c|c|c|c|c|}
\hline \multirow{3}{*}{ Meaning of Result > } & \multicolumn{4}{|c|}{$\begin{array}{l}\text { Economic Allocation, Weight FU } \\
\end{array}$} \\
\hline & \multicolumn{4}{|c|}{ Is the Mean Impact of $j$ at Least 0.2 Standard Deviation Units Significantly Lower than that of $k$ ? } \\
\hline & & No & Yes & \\
\hline \multirow[t]{4}{*}{ Climate Change } & \multirow{4}{*}{$\begin{array}{l}\text { VEG } \\
\text { EGG } \\
\text { CA }\end{array}$} & VEG & EGG & CA \\
\hline & & & no & no \\
\hline & & yes & & yes \\
\hline & & yes & no & \\
\hline \multirow[t]{4}{*}{ Ecotoxicity freshwater } & $\mathrm{j} \downarrow \mathrm{k} \rightarrow$ & VEG & EGG & CA \\
\hline & \multirow{3}{*}{$\begin{array}{l}\text { VEG } \\
\text { EGG } \\
\text { CA }\end{array}$} & & yes & no \\
\hline & & no & & no \\
\hline & & yes & yes & \\
\hline \multirow[t]{4}{*}{$\begin{array}{l}\text { Eutrophication } \\
\text { freshwater }\end{array}$} & \multirow{4}{*}{$\begin{array}{l}\text { VEG } \\
\text { EGG } \\
\text { CA }\end{array}$} & VEG & EGG & CA \\
\hline & & & no & no \\
\hline & & yes & & no \\
\hline & & yes & yes & \\
\hline \multirow[t]{4}{*}{ Eutrophication marine } & \multirow{4}{*}{$\begin{array}{l}\text { VEG } \\
\text { EGG } \\
\text { CA }\end{array}$} & VEG & EGG & $\mathrm{CA}$ \\
\hline & & & no & no \\
\hline & & no & & no \\
\hline & & yes & no & \\
\hline \multirow[t]{4}{*}{$\begin{array}{l}\text { Eutrophication } \\
\text { terrestrial }\end{array}$} & $\mathrm{j} \downarrow \mathrm{k} \rightarrow$ & VEG & EGG & CA \\
\hline & \multirow{3}{*}{$\begin{array}{l}\text { VEG } \\
\text { EGG } \\
\text { CA }\end{array}$} & & no & no \\
\hline & & no & & no \\
\hline & & yes & yes & \\
\hline \multirow[t]{4}{*}{ Ionising radiation, $\mathrm{HH}$} & \multirow{4}{*}{$\begin{array}{l}\text { VEG } \\
\text { EGG } \\
\text { CA }\end{array}$} & VEG & EGG & CA \\
\hline & & & no & no \\
\hline & & yes & & no \\
\hline & & yes & no & \\
\hline \multirow[t]{4}{*}{ Land use } & \multirow{4}{*}{$\begin{array}{l}\text { VEG } \\
\text { EGG } \\
\text { CA }\end{array}$} & VEG & EGG & CA \\
\hline & & & yes & no \\
\hline & & no & & no \\
\hline & & no & yes & \\
\hline \multirow[t]{4}{*}{$\begin{array}{l}\text { Non-cancer human } \\
\text { health effects }\end{array}$} & $\mathrm{j} \downarrow \mathrm{k} \rightarrow$ & VEG & EGG & CA \\
\hline & VEG & & no & no \\
\hline & EGG & no & & no \\
\hline & CA & no & no & \\
\hline \multirow[t]{4}{*}{ Ozone depletion } & \multirow{4}{*}{$\begin{array}{l}\text { VEG } \\
\text { EGG } \\
\text { CA }\end{array}$} & VEG & EGG & CA \\
\hline & & & no & no \\
\hline & & yes & & yes \\
\hline & & yes & no & \\
\hline \multirow[t]{4}{*}{$\begin{array}{l}\text { Photochemical ozone } \\
\text { formation, } \mathrm{HH}\end{array}$} & $\mathrm{j} \downarrow \mathrm{k} \rightarrow$ & VEG & EGG & CA \\
\hline & VEG & & no & no \\
\hline & EGG & yes & & yes \\
\hline & & yes & no & \\
\hline $\begin{array}{l}\text { Resource use, energy } \\
\text { carriers }\end{array}$ & $\mathrm{j} \downarrow \mathrm{k} \rightarrow$ & VEG & EGG & CA \\
\hline & VEG & & no & yes \\
\hline & EGG & yes & & yes \\
\hline & CA & no & no & \\
\hline $\begin{array}{l}\text { Resource use, mineral } \\
\text { and metals }\end{array}$ & $\mathrm{j} \downarrow \mathrm{k} \rightarrow$ & VEG & EGG & CA \\
\hline & VEG & & yes & no \\
\hline & EGG & no & & no \\
\hline & CA & yes & yes & \\
\hline
\end{tabular}


Table A3. Cont.

\begin{tabular}{|c|c|c|c|c|}
\hline & \multicolumn{4}{|c|}{ Economic Allocation, Weight FU } \\
\hline \multirow{2}{*}{ Meaning of Result > } & \multicolumn{4}{|c|}{ Is the Mean Impact of $j$ at Least 0.2 Standard Deviation Units Significantly Lower than that of $k$ ? } \\
\hline & & No & Yes & \\
\hline \multirow[t]{4}{*}{ Respiratory inorganics } & \multirow{4}{*}{$\begin{array}{l}\text { VEG } \\
\text { EGG } \\
\text { CA }\end{array}$} & VEG & EGG & CA \\
\hline & & & no & no \\
\hline & & yes & & no \\
\hline & & yes & yes & \\
\hline \multirow[t]{4}{*}{ Water scarcity } & $\mathrm{j} \downarrow \mathrm{k} \rightarrow$ & VEG & EGG & CA \\
\hline & VEG & & no & no \\
\hline & EGG & no & & yes \\
\hline & CA & no & no & \\
\hline
\end{tabular}

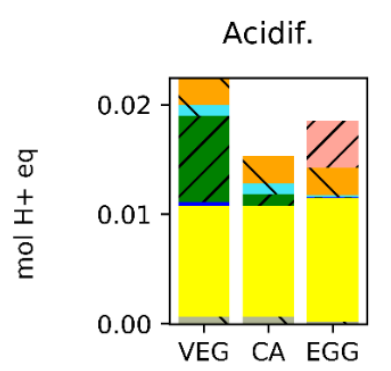

Eutroph. Freshw.

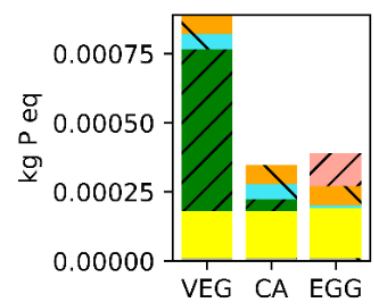

Land Use

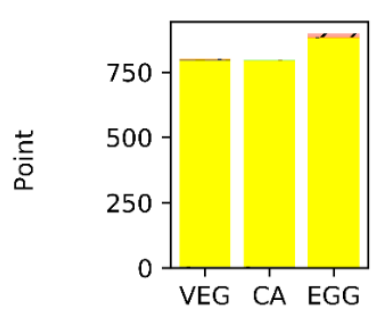

$R U$, energy car.

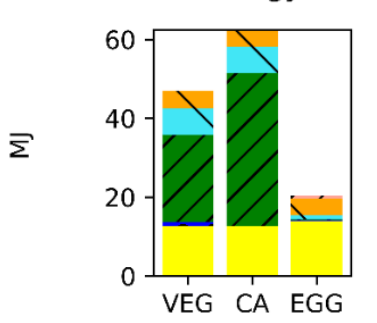

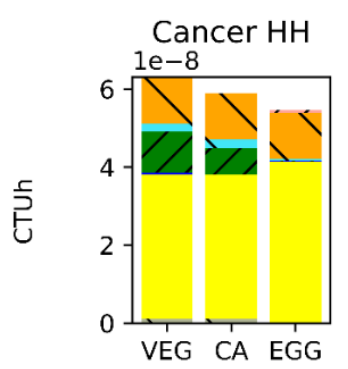

Eutroph. Ma.
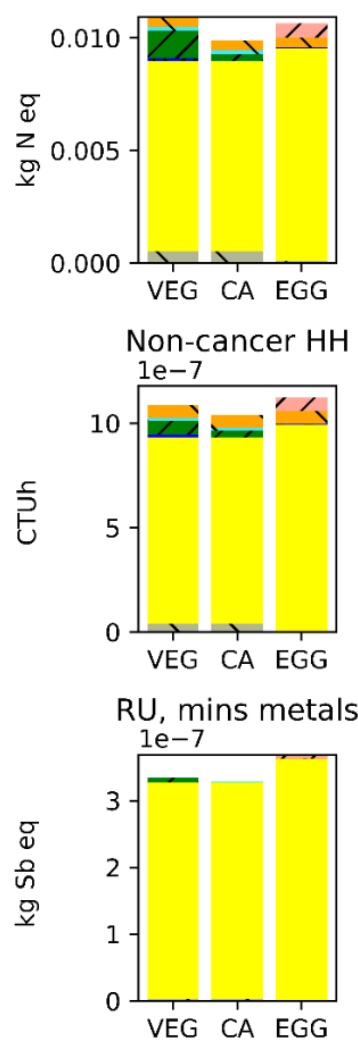
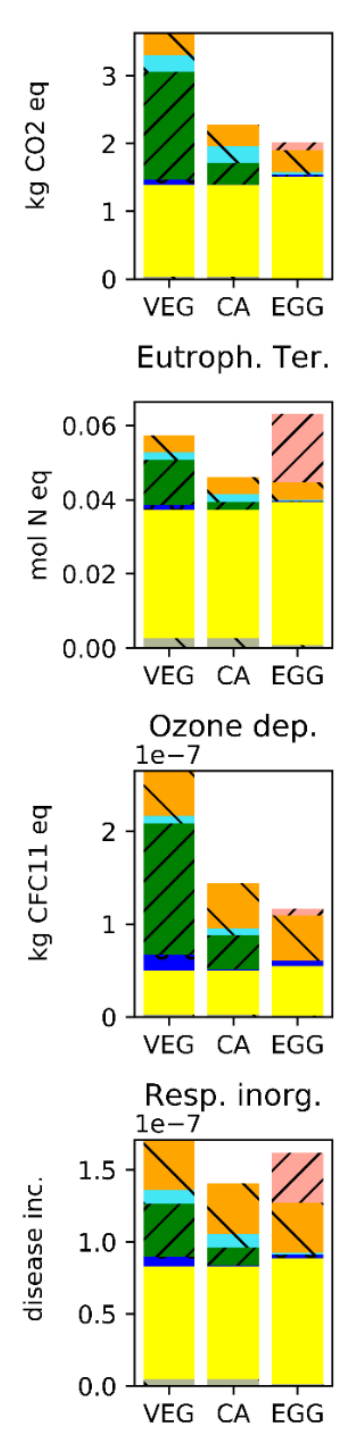

Eutroph. Ter.

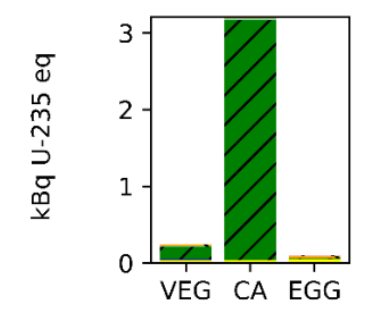

Phot. Oz. form., $\mathrm{HH}$

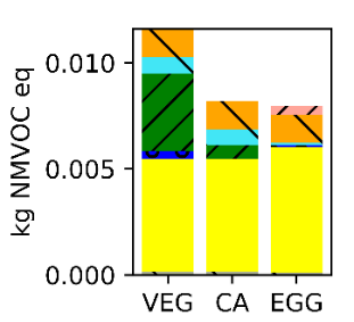

Water scar.

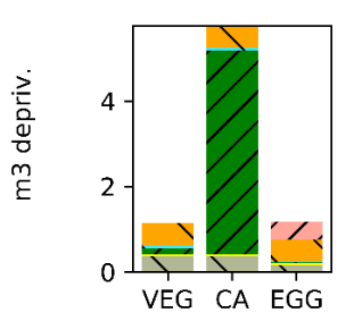

\begin{tabular}{|lll} 
Ingredients assembling & Sunflower oil & Aquafaba/egg processing \\
Other ingredients & Aquafaba/egg transport & Aquafaba/egg packaging
\end{tabular}

Figure A1. Process contributions of egg (EGG), vegan mayonnaise (VEG), and vegan mayonnaise with the Canadian electricity mix for the aquafaba processing (CA) across the sixteen environmental impact categories recommended by the Product Environmental Footprint guidelines. 


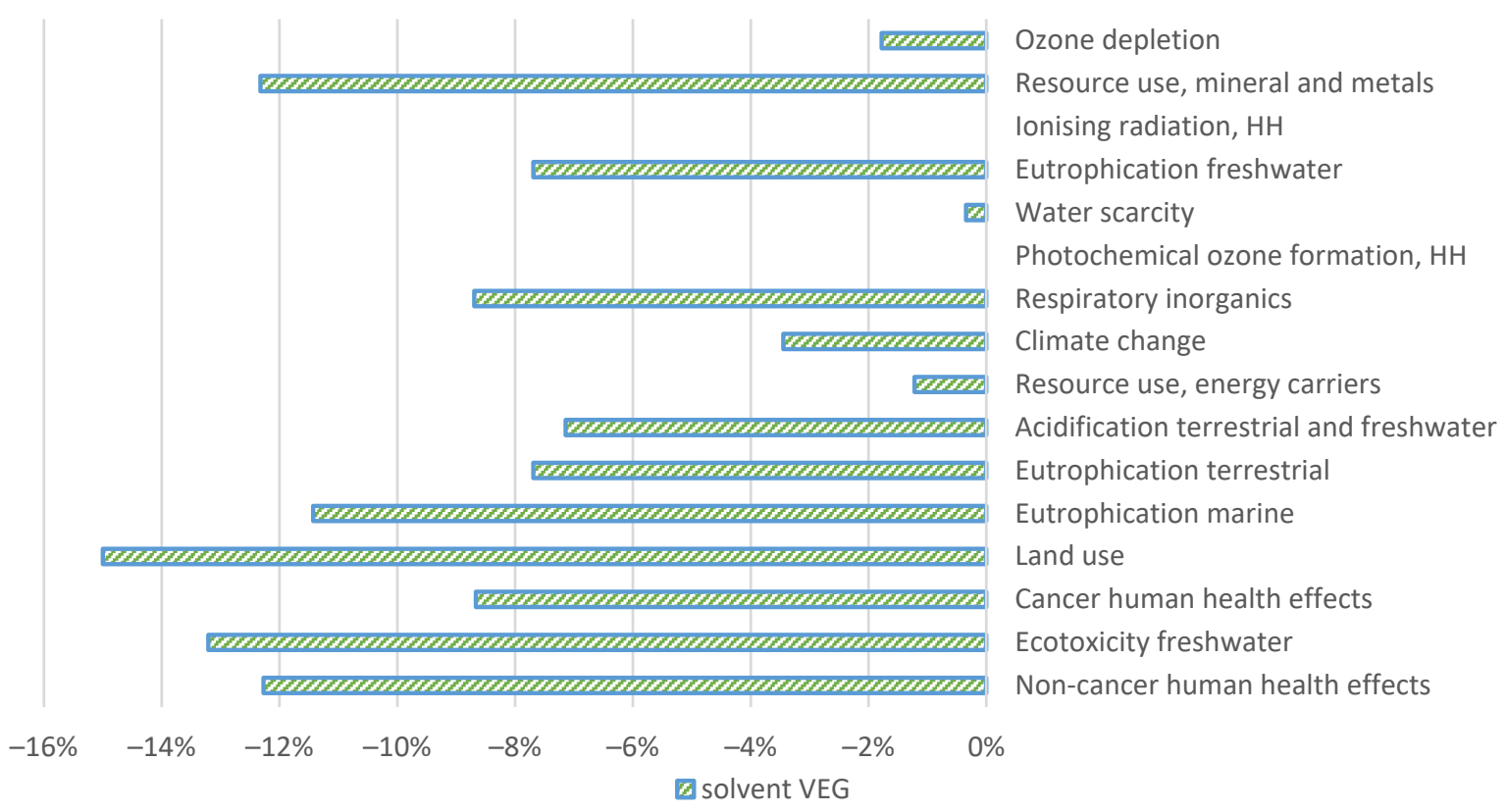

Figure A2. Comparison of one vegan mayonnaise pot made with Argentinian sunflower oil from pressing (reference, on $Y$ axis at $0 \%$ ) and from solvent extraction across the non-toxicity categories recommended by the Product Environmental Footprint guidelines.

Table A4. Comparison of Nutritional comparison of the egg and vegan mayonnaise products per $13 \mathrm{~g}$ serving.

\begin{tabular}{cccc}
\hline & Unit & Egg & Vegan \\
\hline Calories & $\mathrm{kcal}$ & 100 & 90 \\
Total fat & $\mathrm{g}$ & 10 & 10 \\
Saturated fat & $\mathrm{g}$ & 1 & 0.5 \\
Cholesterol & $\mathrm{mg}$ & 10 & 0 \\
Sodium & $\mathrm{mg}$ & 95 & 90 \\
\hline
\end{tabular}

\section{References}

1. Buhl, T.F.; Christensen, C.H.; Hammershøj, M. Aquafaba as an Egg White Substitute in Food Foams and Emulsions: Protein Composition and Functional Behavior. Food Hydrocoll. 2019, 96, 354-364. [CrossRef]

2. Saget, S.; Costa, M.; Santos, C.S.; Vasconcelos, M.W.; Gibbons, J.; Styles, D.; Williams, M. Substitution of Beef with Pea Protein Reduces the Environmental Footprint of Meat Balls Whilst Supporting Health and Climate Stabilisation Goals. J. Clean. Prod. 2021, 297, 126447. [CrossRef]

3. Heller, M.C.; Keoleian, G.A. Beyond Meat's Beyond Burger Life Cycle Assessment: A Detailed Comparison between a Plant-Based and an Animal-Based Protein Source; Report No. CSS18-10; University of Michigan: Ann Arbor, Michigan, 2018.

4. Khan, S.; Dettling, J.; Hester, J.; Moses, R.; Foods, I. Comparative Environmental LCA of the Impossible Burger with Conventional Ground Beef Burger; Quantis: Lausanne, Switzerland, 2019.

5. Masset, G.; Soler, L.G.; Vieux, F.; Darmon, N. Identifying Sustainable Foods: The Relationship between Environmental Impact, Nutritional Quality, and Prices of Foods Representative of the French Diet. J. Acad. Nutr. Diet. 2014, 114, 862-869. [CrossRef]

6. Clark, M.A.; Springmann, M.; Hill, J.; Tilman, D. Multiple Health and Environmental Impacts of Foods. Proc. Natl. Acad. Sci. USA 2019, 116, 23357-23362. [CrossRef]

7. Rosi, A.; Mena, P.; Pellegrini, N.; Turroni, S.; Neviani, E.; Ferrocino, I.; Di Cagno, R.; Ruini, L.; Ciati, R.; Angelino, D.; et al. Environmental Impact of Omnivorous, Ovo-Lacto-Vegetarian, and Vegan Diet. Sci. Rep. 2017, 7, 1-9. [CrossRef]

8. Mustafa, R.; He, Y.; Shim, Y.Y.; Reaney, M.J.T. Aquafaba, Wastewater from Chickpea Canning, Functions as an Egg Replacer in Sponge Cake. Int. J. Food Sci. Technol. 2018, 53, 2247-2255. [CrossRef]

9. Raikos, V.; Hayes, H.; Ni, H. Aquafaba from Commercially Canned Chickpeas as Potential Egg Replacer for the Development of Vegan Mayonnaise: Recipe Optimisation and Storage Stability. Int. J. Food Sci. Technol. 2020, 55, 1935-1942. [CrossRef]

10. Mirzanajafi-Zanjani, M.; Yousefi, M.; Ehsani, A. Challenges and Approaches for Production of a Healthy and Functional Mayonnaise Sauce. Food Sci. Nutr. 2019, 7, 2471-2484. [CrossRef] [PubMed] 
11. Mustafa, R.; Reaney, M.J.T. Aquafaba, from Food Waste to a Value-Added Product. In Food Wastes and By-Products; Wiley: Hoboken, NJ, USA, 2020; pp. 93-126. [CrossRef]

12. Statista. Mayonnaise Usage in France 2014-2018, by Frequency. Available online: https://www.statista.com/statistics/458222 /mayonnaise-usage-by-frequency-in-france/ (accessed on 21 November 2020).

13. Statista. Number of People Using Mayonnaise in Spain in 2018, by Frequency of Use. Available online: https:/ / www.statista. $\mathrm{com} /$ statistics / 434177/mayonnaise-usage-frequency-in-spain/ (accessed on 21 November 2020).

14. Statista. Frequency of Mayonnaise Usage in Great Britain 2016-2018. Available online: https://www.statista.com/statistics/3017 26/mayonnaise-usage-frequency-in-the-uk/ (accessed on 21 November 2020).

15. IMARC. Mayonnaise Market. Share, Size, Trends, Analysis \& Forecast. 2021-2026; IMARC: Noida, Uttar Pradesh, India, 2019.

16. CMR Group. Alimentación En España 2020; CMR Group: Watford, UK, 2020.

17. Poore, J.; Nemecek, T. Reducing Food's Environmental Impacts through Producers and Consumers. Science 2018, 360, 987-992. [CrossRef]

18. Damian, J.J.; Huo, S.; Serventi, L. Phytochemical Content and Emulsifying Ability of Pulses Cooking Water. Eur. Food Res. Technol. 2018, 244, 1647-1655. [CrossRef]

19. ISO. ISO 14040:2006 -Environmental Management_Life Cycle Assessment_Principles and Framework; ISO: Gevena, Switzerland, 2006.

20. Notarnicola, B.; Sala, S.; Anton, A.; McLaren, S.J.; Saouter, E.; Sonesson, U. The Role of Life Cycle Assessment in Supporting Sustainable Agri-Food Systems: A Review of the Challenges. J. Clean. Prod. 2017, 140, 399-409. [CrossRef]

21. Hetherington, A.C.; Mcmanus, M.C.; Gray, D.A. Carbon Foot-Print Analysis and Life Cycle Assessment of Mayonnaise Production. A Comparison of Their Results and Messages. In SETAC; University of Bath: Bath, UK, 2012; pp. $26-28$.

22. Cleveland, D.A.; Gee, Q.; Horn, A.; Weichert, L.; Blancho, M. How Many Chickens Does It Take to Make an Egg? Animal Welfare and Environmental Benefits of Replacing Eggs with Plant Foods at the University of California, and Beyond. Agric. Hum. Values 2020, 38, 157-174. [CrossRef]

23. ComRes. Eurogroup for Animals/Compassion in World Farming-Fish Welfare Survey; ComRes: London, UK, 2018.

24. Global Data. Top. Trends in Prepared Foods 2017: Exploring Trends in Meat, Fish and Seafood; Pasta, Noodles and Rice; Prepared Meals; Savory Deli Food; Soup; and Meat Substitutes; Global Data: London, UK, 2017.

25. Statista. Number of vegans Great Britain from 2014 to 2018. Available online: https://www.statista.com/statistics/1062104/ number-of-vegans-in-great-britain/ (accessed on 21 November 2020).

26. JUST Egg. JUST Egg I Made from Plants. Available online: https:/ / www.ju.st/ (accessed on 21 November 2020).

27. Vegg. Vegg. Available online: https://thevegg.com/ (accessed on 21 November 2020).

28. Eunite Foods. The Egg. Available online: https://www.eunitefoods.com/ (accessed on 21 November 2020).

29. Eggcitables. Eggcitables! A Gluten-Free Alternative to Eggs. Available online: https:/ / www.eggcitables.com/ (accessed on 21 November 2020).

30. Bob's Red Mill. Vegan Egg Substitute \& Replacement-Gluten Free. Available online: https://www.bobsredmill.com/gluten-freevegan-egg-replacer.html (accessed on 21 November 2020).

31. Nette, A.; Wolf, P.; Schlüter, O.; Meyer-Aurich, A.; Nette, A.; Wolf, P.; Schlüter, O.; Meyer-Aurich, A. A Comparison of Carbon Footprint and Production Cost of Different Pasta Products Based on Whole Egg and Pea Flour. Foods 2016, 5, 17. [CrossRef] [PubMed]

32. GreenDelta. OpenLCA. Available online: https://www.openlca.org/download/ (accessed on 21 November 2020).

33. Durlinger, B.; Koukouna, E.; Broekema, R.; Van Paassen, M.; Scholten, J. Agri-Footprint 3.0; Blonk Consultants: Gouda, The Netherlands, 2017.

34. Wernet, G.; Bauer, C.; Steubing, B.; Reinhard, J.; Moreno-Ruiz, E.; Weidema, B. The Ecoinvent Database Version 3 (Part I): Overview and Methodology. Int. J. Life Cycle Assess. 2016, 21, 1218-1230. [CrossRef]

35. European Commission. Product Environmental Footprint Category Rules Guidance; No. 6.3; European Commission: Luxembourg, 2018.

36. Mendoza Beltran, A.; Prado, V.; Font Vivanco, D.; Henriksson, P.J.G.; Guinée, J.B.; Heijungs, R. Quantified Uncertainties in Comparative Life Cycle Assessment: What Can Be Concluded? Environ. Sci. Technol. 2018, 52, 2152-2161. [CrossRef]

37. Searates. Distances \& Time. Available online: https:/ / www.searates.com/services/distances-time/ (accessed on 21 November 2020).

38. Morgan, A.; Stichnothe, H.; Azapagic, A. Carbon Calculations over the Life Cycle of Industrial Activities-CCaLC(C) Tool Manual; University of Manchester: Manchester, UK, 2010.

39. European Commission. International Reference Life Cycle Data System (ILCD) Handbook—General Guide for Life Cycle AssessmentDetailed Guidance; European Commission: Luxembourg, 2010.

40. Tsai, J.H.; Huang, J.Y.; Wilson, D.I. Life Cycle Assessment of Cleaning-In-Place Operations in Egg Yolk Powder Production. J. Clean. Prod. 2021, 278, 123936. [CrossRef]

41. Pelletier, N.; Ibarburu, M.; Xin, H. A Carbon Footprint Analysis of Egg Production and Processing Supply Chains in the Midwestern United States. J. Clean. Prod. 2013, 54, 108-114. [CrossRef]

42. Belyavin, C.G. Eggs: Use in the Food Industry. In Encyclopedia of Food and Health; Elsevier Inc.: Amsterdam, The Netherland, 2015; pp. 476-479. [CrossRef]

43. Réhault-Godbert, S.; Guyot, N.; Nys, Y. The Golden Egg: Nutritional Value, Bioactivities, and Emerging Benefits for Human Health. Nutrients 2019, 11, 684. [CrossRef] 
44. van der Weele, C.; Feindt, P.; Jan van der Goot, A.; van Mierlo, B.; van Boekel, M. Meat Alternatives: An Integrative Comparison. In Trends in Food Science and Technology; Elsevier Ltd.: Amsterdam, The Netherland, 2019; pp. 505-512. [CrossRef]

45. Alexander, P.; Brown, C.; Arneth, A.; Dias, C.; Finnigan, J.; Moran, D.; Rounsevell, M.D.A. Could Consumption of Insects, Cultured Meat or Imitation Meat Reduce Global Agricultural Land Use? In Global Food Security; Elsevier B.V.: Amsterdam, The Netherland, 2017; pp. 22-32. [CrossRef]

46. Smetana, S.; Aganovic, K.; Irmscher, S.; Heinz, V.C. (pp. 145-155) Agri-Food Waste Streams Utilization for Development of More Sustainable Food Substitutes. In Designing Sustainable Technologies, Products and Policies; Springer: Berlin, Germany, 2018; pp. 469-474. [CrossRef]

47. Mexican Government. Estrategia de Transición Para Promover El Uso de Tecnologías y Combustibles Más Limpios I Comisión Nacional Para El Uso Eficiente de La Energía; Mexican Government: Mexico City, Mexico, 2020.

48. Searchinger, T.D.; Wirsenius, S.; Beringer, T.; Dumas, P. Assessing the Efficiency of Changes in Land Use for Mitigating Climate Change. Nature 2018, 564, 249-253. [CrossRef]

49. Foster, R.; Williamson, C.S.; Lunn, J. BRIEFING PAPER: Culinary Oils and Their Health Effects. Nutr. Bull. 2009, $34,4-47$. [CrossRef]

50. Wolters, M.; Ahrens, J.; Romaní-Pérez, M.; Watkins, C.; Sanz, Y.; Benítez-Páez, A.; Stanton, C.; Günther, K. Dietary Fat, the Gut Microbiota, and Metabolic Health-A Systematic Review Conducted within the MyNewGut Project. Clin. Nutr. 2019, 38, 2504-2520. [CrossRef]

51. Cândido, F.G.; Valente, F.X.; Grześkowiak, Ł.M.; Moreira, A.P.B.; Rocha, D.M.U.P.; Alfenas, R.D.C.G. Impact of Dietary Fat on Gut Microbiota and Low-Grade Systemic Inflammation: Mechanisms and Clinical Implications on Obesity. Int. J. Food Sci. Nutr. 2018, 69, 125-143. [CrossRef]

52. OECD. Obesity Updates; OECD: Paris, France, 2017.

53. Spence, J.D.; Jenkins, D.J.A.; Davignon, J. Dietary Cholesterol and Egg Yolks: Not for Patients at Risk of Vascular Disease. Can. J. Cardiol. 2010, 26, e336-e339. [CrossRef]

54. Schmidt, J.H. Life Cycle Assessment of Five Vegetable Oils. J. Clean. Prod. 2015, 87, 130-138. [CrossRef]

55. Hayek, M.N.; Harwatt, H.; Ripple, W.J.; Mueller, N.D. The Carbon Opportunity Cost of Animal-Sourced Food Production on Land. Nat. Sustain. 2020, 4, 21-24. [CrossRef]

56. Ballco, P.; Caputo, V.; de-Magistris, T. Consumer Valuation of European Nutritional and Health Claims: Do Taste and Attention Matter? Food Qual. Prefer. 2020, 79, 103793. [CrossRef] 